\title{
Phthalate induced toxicity in prostate cancer cell lines and effects of alpha lipoic acid
}

\author{
Kismali $\mathrm{G}^{1}$, Yurdakok-Dikmen $\mathrm{B}^{2}$, Kuzukiran $\mathrm{O}^{3}$, Arslan $\mathrm{P}^{4}$, Filazi $\mathrm{A}^{2}$ \\ Ankara University Faculty of Veterinary Medicine, Department of Biochemistry, Ankara, Turkey. \\ gorkemkismali@yahoo.com
}

\begin{abstract}
OBJECTIVE: The effects of dimethyl phthalate, diethyl phthalate, diisobutyl phthalate, di-n-butyl phthalate, benzylbutyl phthalate, di-2-ethylhexyl phthalate were investigated on human prostate cancer cell lines DU145 and PC3 in vitro.

MATERIALS AND METHODS: Standards of dimethyl phthalate, diethyl phthalate, di-isobutyl phthalate, dibutyl phthalate, benzyl butyl phthalate, and di-ethyl hexyl phthalate were used. Alpha lipoic acid was used as antioxidant compound. DU145 and PC3 human prostate carcinoma cells were used. MTT assay were used for cytotoxicity assay.

RESULTS: A low dose proliferative effect of phthalates in vitro was observed. With the hypothesis of the inhibition of aerobic glycolysis activity in cancer treatment, a-lipoic acid was applied to cells; where as a contrary to previous studies, no change in the cell proliferation was observed. In combination with ALA, at IC50 and lower doses, an increase of the cytotoxic effect was found for DIBP, DBP and BBP; while for DMP, DEP and DEHP, a decrease was observed for DU145 cells. In PC3 cells, a decrease was observed for DMP, DEP and DBPs; while no significant difference were observed for DEHP, DIBP and BBP.

CONCLUSSION: The present study demonstrates preliminary information regarding the low dose proliferative effects of phthalates in prostate cancer in vitro (Tab. 2, Fig. 2, Ref. 65). Text in PDF www.elis.sk. KEY WORDS: phthalate, prostate cancer, DU145, PC3, alpha lipoic acid, in vitro.
\end{abstract}

\section{Introduction}

Prostate cancer, as among the most commonly diagnosed cancer in men; has no effective treatment; while steroid hormones such as androgen were found to influence their growth and survival. Prostate cancer was found to be an ideal candidate for exogenous preventive measures, such as dietary and pharmacological prevention, due to the high prevalence, long latency, endocrine dependency, availability of serum markers (e.g. prostate-specific antigen) and the histological precursor lesions. However, there is currently no strong evidence to suggest that dietary interventions can reduce/induce the risk of prostate cancer (1).

Alpha lipoic acid (ALA), a naturally occurring cofactor, is important in the assortment of enzyme complexes controlling metabolism, including the conversion of pyruvate to energy in the mitochondrion. This compound is shown to be included in a variety of biological process associated with oxidative stress, including cancer $(2,3)$. ALA was found to generate reactive oxygen

\footnotetext{
${ }^{1}$ Ankara University Faculty of Veterinary Medicine, Department of Biochemistry, Ankara, Turkey, ${ }^{2}$ Ankara University Faculty of Veterinary Medicine, Department of Pharmacology and Toxicology, Ankara, Turkey, ${ }^{3}$ Etlik Veterinary Control Central Research Institute, Ankara, Turkey, and ${ }^{4}$ Ankara University Faculty of Biology, Ankara, Turkey

Address for correspondence: G. Kismali, PhD, Ankara University, Faculty of Veterinary Medicine, Department of Biochemistry, 06110 Ankara, Turkey.

Phone: +90.3123170315/4424, Fax: +903123176073
}

species (ROS), triggering the mitochondrial pathway of apoptosis in cancer cells, which contributes ALA-dependent cell death in various types of cancer cells in experimental studies, including lung $(4,5)$ colon, $(6)$ breast $(7,8)$, leukemia $(9,10)$ and liver (11). Due to its powerful antioxidant capacity and importance in glycose metabolism by supporting pyruvate dehydrogenase reaction and oxidation of glycose, ALA has turned into a promising complementary therapeutic agent in the eradication of tumor cells. The mechanism of action of ALA is complex and differs according to the cancerous cell type (12). ALA was found to inhibit the second messenger NF- $\mathrm{kB}$ (nuclear factor $\mathrm{kB}$ ), leading to decreased proliferation, metastasis, invasion, chemo/radio resistance and inflammation of cancer cells (13-15). ALA was found to induce the hyperacetylation of histones related to the proliferation of many types of cancer cells, which would eventually lead to apoptosis (16). As mentioned previously, the increased uptake of oxidizable substrates into the mitochondrion of cancerous cells also stimulate apoptosis. Antimutagenic and anticlastogenic effects of this compound has also been studied $(17,18)$. Due to its anti-inflammatory property, protective effects on nerve damage and neuropathy from chemo drugs like the platinum, related to its anti-inflammatory property were also described previously $(19,20)$. Epidemiology and experimental research indicate discordance for the relationship between ALA and prostate cancer. Increased risk has been associated previously (21-23). Azrad et al (23) defined the genetic variation related to ALA metabolism, 
where the prostatic ALA, independent of diet, was found to be significantly and positively associated with biomarkers of aggressive disease affecting the tumor proliferation rates. Meanwhile, these studies show drawbacks such as collection of the accurate dietary data, inter-individual differences in the metabolism of ALA or the sampling sizes (24).

Phthalates, known as the plasticizers (making plastics more flexible or soft), have a variety of commercial uses, including personal-care products (e.g. perfumes, lotions, cosmetics), paints, food, construction industry, and certain medical devices and pharmaceuticals (25). These ubiquitous environmental, endocrine disrupting contaminants, were found to have adverse effects on male reproductive health $(26,27)$. Irreversible changes in the male reproductive tract due to phthalate exposure, even in the prenatal period, is shown to interfere with the androgen signaling pathway, causing permanent adverse effects on reproductive development corresponding a decline in male fertility due to changes in sperm concentration and semen quality. These compounds are also associated with an impaired development and alter the regular function of prostate (26). Exposure to DEHP (di-2-ethylhexyl phthalate), DEHA (di(2-ethylhexyl)adipate), (28) and DIBP (diisobutyl phthalate) (29) in the diet, were found to result in decreased weight of the prostate.

The effects of phthalates on prostate cancer cells were studied extensively especially in LNCaP cells; since this cell line was found to express estrogen receptor- $\alpha$, estrogen receptor- $\beta$ and androgen receptors (ARs), which were linked to the endocrine disrupting property of phthalates. DBP was found to promote LN$\mathrm{CaP}$ prostate cancer proliferation through the crosstalk between TGF- $\beta$ and ER signaling pathway (30). Meanwhile, Hruba et al (31) showed that, at lower concentrations, DEHP $(50 \mu \mathrm{M})$ and DBP $(50 \mu \mathrm{M})$ were found to suppress cell cycle proliferation in a dose-dependent manner through induction of accumulation of cells within G1 phase of the cell cycle. Previously, DEHP (3 mM) and its main metabolite MEHP (mono(2-ethylhexyl)phthalate-3 $\mu \mathrm{M})$ caused production of reactive oxygen species, activation of p53 tumor suppressor and induction of p21WAF/Cip1cyclindependent kinase inhibitor; where this effect was inhibited by selenium (32). DBP was also shown to promote LNCaP cell proliferation by upregulating the gene expression of c-myc and cyclin D1 and by downregulating the expression of p21 (15). DEHP was also found to weakly reduce AR protein levels after long-term exposure (8 days), while only DBP partially inhibited expression of the prostate-specific antigen (KLK3) gene, a model AR transcriptional target. Overall, it was stated that DEHP and DBP may have negative effects on the proliferation of LNCaP cells, independent of AR modulations. Possible involvement of AR or phenotypic changes such as modulation of neuroendocrine trans differentiation (NED) due to phthalate exposure are still unknown (31). The relationship between phthalate/alpha lipoic acid and male reproduction has recently been studied in an in vivo model. Bi-n-butyl phthalate (BNBBP) was found to cause testicular toxicity through testosterone, follicule stimulating hormones (FSH) and antioxidant enzymes in Wistar rats; where ALA was found to mitigate BNBP-induced testicular toxicity through antioxidant mechanism and by direct free radical scavenging activity (33).

While the majority of the prostatic cancers are adenocarcinomas characterized by the expression of luminal differentiation markers AR and prostate-specific antigen (PSA), where LNCaP cells are used as the main in vitro model; androgen independent models DU-145 and PC3 (as a model for small cell neuroendocrine carcinoma) are used in studies for the evaluation of the effects of chemicals independent of AR and more aggressive phenotypes $(34,35)$. Therefore, the aim of the current study was to evaluate the effects of phthalates on androgen independent cell lines DU-145 and PC3 and to assess the possible interaction with the antioxidant ALA.

\section{Materials and method}

\section{Chemicals}

Standards of dimethyl phthalate (DMP), diethyl phthalate (DEP), di-isobutyl phthalate (DIBP), dibutyl phthalate (DBP), benzyl butyl phthalate (BBP), and di-ethyl hexyl phthalate (DEHP) were purchased from Dr. Ehrenstorfer (Augsburg, Germany). Alpha lipoic acid (DL-Thioctic acid, 98+\%) was purchased from Acros Organics (New Jersey, USA).

\section{Cell culture conditions}

DU145 (HTB-81) human prostate carcinoma cells derived from the brain metastatic site and PC3 (CRL-1435), grade IV human prostate adenocarcinoma cells derived from the bone metastatic site used in the study were acquired from the American Type Culture Collection (ATCC ${ }^{\mathrm{TM}}$ ). All cell culture procedures were performed under strict sterile conditions and kept inside a $5 \% \mathrm{CO}_{2}$ incubator at $37{ }^{\circ} \mathrm{C}$. Cells were cultivated using RPMI 1640 medium (Gibco $\left.{ }^{\circledR}\right)$ supplemented with $10 \%$ fetal bovine serum (Thermo Fisher Scientific) and penicillin-streptomycin (100 U/ml, Thermo Fisher Scientific). Cell culture medium was replaced every other day. Cell growth was checked using phasecontrast microscopy.

\section{Cytotoxicity}

Sub-culturing and/or cell cultivation was carried out when a confluent monolayer of cells was observed over the majority of growth surface via Juli FL software (Seoul, Korea). For the cytotoxicity assays, cells were seeded in 96-well microplates at a density of $3 \times 10^{4}$ cells $/ \mathrm{mL}$ in $100 \mu \mathrm{L}$. The microplates were incubated for $24 \mathrm{~h}$ to allow for cell attachment and growth in the plates while the following day $20 \mu \mathrm{L}$ phthalate was added to the media for another $24 \mathrm{~h}$ incubation for cytotoxicity assays of MTT ((3-(4,5-dimethylthiazol-2-yl)2,5-diphenyl tetrazolium bromide). Based on the preliminary assays, half dilutions between $0.0061-$ $12.5 \mu \mathrm{g} / \mathrm{ml}$ for DMP, DIBP and BBP; $0.0002-0.5$ for DEP and DBP; $0.0006-1.25 \mu \mathrm{g} / \mathrm{ml}$ were applied. Concentration of alpha lipoic acid was decided according to preliminary cytotoxicity studies and our previous study (10). Treatments at each dose were conducted at three replicates in the same plate and all the experiments were repeated four times. Medium only and $0.1 \%$ Triton 
460-466

$\mathrm{X}-100$ served as negative and positive controls, respectively. MTT assays were performed soon after the incubation. Cell viability was quantified using SpectraMax i3/i3x Multi-Mode Detection Platform (Molecular Devices, Sunnyvale, CA) at $540 \mathrm{~nm}$ for MTT.

\section{Statistical analysis}

Percent cytotoxicity were calculated for each concentration using Microsoft Excel computer program. Regression analysis was done using the plotted values against the corresponding doses by SPSS 17.0 where the highest correlation coefficient (R2) is selected for the fit and IC50 values are calculated. Results for ALA and phthalate combination were presented as the means \pm SDs. Statistical analysis was done using one way analysis of variance (ANOVA) for multiple samples and Student's t-test for comparing paired sample sets. $\mathrm{p}$ values less than 0.05 were considered statistically significant.

\section{Results}

Ic50 Values for the Tested Phthalates: Among the tested phthalates, DEHP induced the highest cytoxocity on DU 145 cells; where the least cytotoxic compound was DMP in the same cell line. PC3 cells were more susceptible to DMP, DEP and BBP than DU 145 cells $(p>0.05)$. Among average IC50 values for both cells, the most cytotoxic compound was DEHP followed by DBP. PC3 cells were found to be more susceptible to the tested phthalates compared to DU 145 cells (Tab. 1).

Phthalate Combination with Alpha Lipoic Acid: Following the co-administration of ALA with IC50 doses of pyrethroids, an

Tab. 1. IC50 values (ppb) of tested phthalates on prostate cancer cells.

\begin{tabular}{lcc}
\hline & DU 145 & PC 3 \\
\hline Dimethyl phthalate (DMP) & 2390.48 & 1301.78 \\
Diethyl phthalate (DEP) & 1905.53 & 477.13 \\
Diisobutyl phthalate (DIBP) & 449.74 & 785.80 \\
Di-n-butyl phthalate (DBP) & 27.32 & 77.21 \\
Benzylbutyl phthalate (BBP) & 93.15 & 44.25 \\
Di-2-ethylhexyl phthalate (DEHP) & 22.82 & 78.69 \\
\hline
\end{tabular}

Tab. 2. Phthalate combination with alpha lipoic acid for DU145 and PC3 cell lines.

\begin{tabular}{lcc}
\hline & DU 145 & PC 3 \\
\hline ALA & $50.77 \pm 3.23$ & $-22.13 \pm-2.00$ \\
DMP & $81.25 \pm 0.62$ & $38.15 \pm 2.24$ \\
DMP+ALA & $56.66 \pm 0.19$ & $11.57 \pm 0.95$ \\
DEP & $84.34 \pm 0.45$ & $34.81 \pm 3.44$ \\
DEP+ALA & $65.22 \pm 4.62$ & $17.80 \pm 1.97$ \\
DEHP & $90.00 \pm 16.30$ & $47.97 \pm 0.14$ \\
DEHP+ALA & $58.11 \pm 0.87$ & $48.39 \pm 3.97$ \\
DIBP & $60.66 \pm 6.72$ & $17.88 \pm 3.46$ \\
DIBP+ALA & $63.27 \pm 3.15$ & $17.64 \pm 2.84$ \\
DBP & $95.84 \pm 0.45$ & $32.74 \pm 2.83$ \\
DBP+ALA & $54.67 \pm 1.00$ & $16.72 \pm 1.41$ \\
BBP & $78.23 \pm 0.18$ & $30.35 \pm 3.26$ \\
BBP+ALA & $58.20 \pm 0.10$ & $28.00 \pm 2.44$ \\
\hline
\end{tabular}

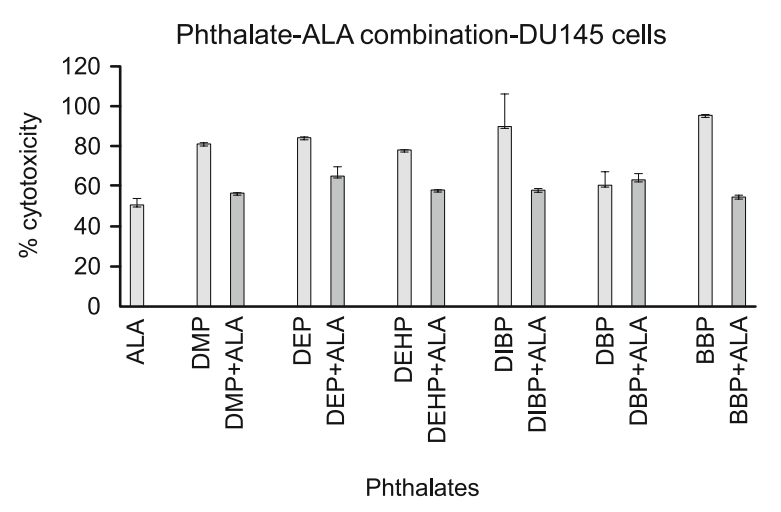

Fig. 1. Phthalate combination with alpha lipoic acid for DU145 cell line.

Phthalate-ALA combination-PC3 cells

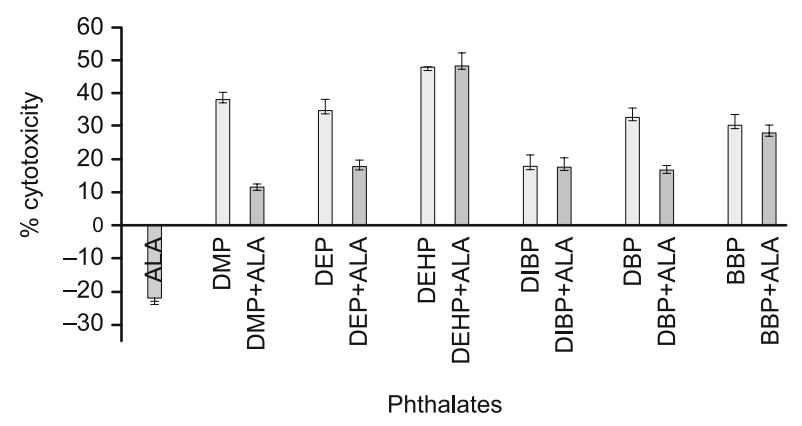

Fig. 2. Phthalate combination with alpha lipoic acid for PC3 cell line.

increase of the cytotoxic effect were found for DIBP, DBP and BBP (13.09, 25.22, $5.36 \%$, respectively); while for DMP, DEP and DEHP, a decrease $(9.27,8.12,7.76 \%$, respectively) was observed for DU145 cells (Fig. 1 a, Tab. 2). In PC3 cells, a decrease was observed for DMP, DEP and DBPs (26.58, 17.01 and 16.02 $\%$, respectively); while no significant difference were observed for DEHP, DIBP and BBP ( $p>0.05)$ (Fig. 2, Tab. 2).

\section{Discussion}

Endocrine disrupting compounds were found to influence the development and progression of prostate cancer mainly through estrogen reprogramming of the prostate gland resulting permanent alterations and gene expression for prostatic lesions with aging $(36,37)$. Epidemiologic evidence linked prostate cancer and environmental contaminants with endocrine disrupting potential such as pesticides (chlorpyrifos, fonofos, coumaphos, phorate, permethrin) (38-40) bisphenol A (41), PCBs (42), dioxin (43), cadmium (44), and arsenic (45) which are known to have estrogenic activities. Estrogens have been implicated as potential agents in the development and progression of prostate cancer through hormonal dysregulation, hyperprolactinemia, inflammation, which would lead mutations and DNA damage and epigenotoxigenic pathways $(46,47)$. 
In order to study the genetic and molecular changes of prostate cancer development and progression, in vitro culture models such as LNCaP, DU145, PC3 and TSU-Pvl were developed. In the nuclear compartment of $\mathrm{PC} 3$ cells, the presence of high affinity estrogen binding sites were reported; indicating the evidence for a specific estrogen receptor; where significant proliferative activity was inhibited (48). This was supported by Matsumura et al (49) where phytoestrogengenistein was found to inhibit the proliferative activity and induced the expression of $\mathrm{p} 21$, a regulator of cell cycle progression and ER $\beta$ in the PC-3 cells. Lau et al (50) tested the receptor-mediated estrogenic and antiestrogenic action of normal and malignant prostatic epithelial cells; where LNCaP cells (androgen-sensitive human prostate adenocarcinoma cells) were found to express $\operatorname{Er} \beta$, and estrogen responsive genes (progesterone receptor and pS2), DU145 expressed ER- $\beta$ and PR, and PC-3 cells exhibited ER- $\alpha$, ER- $\beta$, and pS2 mRNA. Relative potencies of their estrogenic activities of the phthalate compounds tested in the current study descended in the order $\mathrm{BBP}>\mathrm{DiBP}>\mathrm{DBP}>$ DEHP $>$ DEP $>$ DMP; where BBP showed its estrogenic activity mainly through $\operatorname{Er} \beta$. DMP and DEP did not induce Er $\alpha-\beta$ agonism or $\operatorname{Er} \beta / A R$ antagonism (51). In the current study, the least toxic compounds on both cells were DEP and DMP, this would suggest a possible estrogen receptor dependency for the toxic effects of these two compounds. Also in the current study, DMP, DEP and BBP induced less cytotoxic effects on DU145 cells than PC-3 and vice versa for DIBP, DBP and DEHP cells. Even though DU145 and PC3 were reported to be AR negative (52), both cells were found to express detectable levels of AR mRNA and protein, where levels of AR protein were found to increase after the androgen ligand (dihydrotestosterone) treatment (53). The expression of AR in PC3 and DU145 cell line were found to inhibit the cell proliferation; through upregulation of $\mathrm{p} 21$ by androgen signaling through $\operatorname{AR}(53,54)$. From this point, androgen antagonist phthalates such as DiBP, DBP and BBP would expected to have lower cytotoxic activity; meanwhile DMP and DEP (not AR antagonism) were found to have the least cytotoxicity. For DiBP, DBP and BBP; relative inhibitory concentration (RIC20) for AR antagonistic activity were found as $6.2 \times 10^{-6}$, $4.8 \times 10^{-6}, 2.9 \times 10^{-6} \mathrm{M}(51)$ respectively; while IC50 values in the current study for the same compounds were $1.44 \times 10^{-6}, 1.23 \times 10^{-7}$ and $3.3 \times 10^{-7} \mathrm{M}$ for DU-145 cells; $2.51 \times 10^{-6}, 3.47 \times 10^{-7}, 1.59 \times 10^{-7}$ for PC-3 cells. Since the concentration for the cytotoxic effects of DBP and BBP are lower than the levels causing possible antiandrogenic effects, AR pathway could not be attributed directly. AR are linked to different phosphorylation sites, which are expected to induce different functions and phosphorylation process is cell type specific,(51) the differences in the cytotoxic effects between DU-145 and PC-3 along with the different types of phthalates, might be related to the AR, ER receptor affinity and phosphorylation of these receptors.

Erßas, a mediator of epithelial differentiation and as an antiproliferative molecule, regulating many molecular pathways including upregulation of apoptotic genes (55) is expressed in both DU145 and PC3 cells (50). Among phthalates, BBP, which effects directly as an agonist for $\operatorname{Er} \beta$ (51), is expected to have higher tu- mor-suppressing function (55). This was confirmed in the current study for BBP, being the most cytotoxic compound in PC-3 cells, which express both $\operatorname{Er} \beta$ and Er $\alpha$. Interestingly, BBP was found to be the third cytotoxic compound in DU145 cells, which express $\operatorname{Er} \beta$ only. Recently, the opposing roles of ER $\alpha$ and ER $\beta$ in prostate cancer are under discussion; (56) since the tumor-promoting roles of ER $\beta 2$ and ER $\beta 5$ isoforms were identified. Since these isoforms play an important role in tumor progression and currently, no information is available for phthalates, further studies are required to understand estrogen receptor mediated effects of phthalates in prostate cancer.

Neuroendocrine differentiation (NED) as a structural and functional feature of prostate cancer, appears during advanced stages, and found to be responsible for treatment resistance and poor prognosis.(57) Androgen depletion is also correlated to the induction of NED in prostate cancer cells in vitro $(54,58)$. Meanwhile, androgen-deprivation conditions did not induce NED in PC3 and DU145 cells (59). Therefore, the results of the current study could not be discussed within NED perspective; while neuron-specific enolase and chromogenin A expression could be studied in future.

Contradictory results in the previous studies with $\mathrm{LNCaP}$ cell lines and phthalates, raise concerns over more complicated molecular mechanisms behind the mechanism of action of these compounds. DBP at $1 \mu \mathrm{M}$ treatment induced cell proliferation; (30) while at $50 \mu \mathrm{M}$ decreased cell proliferation independent from AR expression and activity (31). DEHP induced cytoxicity at 3 $\mathrm{mM}$ concentration through induction of reactive oxygen species (ROS) and activation of nuclear p53 and p21 proteins; (60) while this effect was found at much lower concentrations $(50 \mu \mathrm{M})$ in the study by Hruba et al (31) Experimental and epidemiological evidence for the non-monotonic dose response relationship of endocrine disrupting compounds reveal a need for different strategic methods for the risk assessment of these substance in human health (61). Among these compounds, phthalates were found to induce adverse effects at low concentrations (62). Low dose exposure to DEHP (100 $\mu \mathrm{g} \mathrm{DEHP/kg/day)} \mathrm{was} \mathrm{found} \mathrm{to} \mathrm{alter} \mathrm{sperm}$ morphology and chromatin DNA damage leading sperm toxicity in rats (63), and increase susceptibility to testicular autoimmunity (increase in IFN- $\gamma$ positive cells) and damage to blood testis barrier in mice (64).

The use of the powerful antioxidant, ALA; which is involved in many important biological and biochemical cellular processes, is used in the ancillary treatment of many diseases, such as diabetes, cardiovascular, neurodegenerative, autoimmune diseases, cancer and $\operatorname{AIDS}(3,11,12)$. Meanwhile, their use as a potential anti-cancer agent is discussed for prostatic cancer patients where epidemiologic and experimental researches indicate discordance (24). Recently, prostatic ALA, was significantly and positively associated with biomarkers of aggressive prostatic cancer progression and tumor proliferation rates (21-23). Choi et al (65) studied the effects of ALA on the antioxidant system in prostatic cancer cells PC-3, LNCaP, and RWPE-2 cell lines where the expression of Ref- 1 protein was increased with 125 , 250 , and $500 \mu \mathrm{M}$ of ALA in PC-3 significantly. Treatment of LN- 
460-466

$\mathrm{CaP}$ cells with increasing concentrations of $\operatorname{ALA}(0,0.125,0.5$, $1,10,125,250,500 \mu \mathrm{M}, 1 \mathrm{mM}$, and $2 \mathrm{mM}$ ) resulted in a dosedependent decrease in cell viability, where significant induction of cell loss was observed at $250 \mu \mathrm{M}$; whereas no information is available for PC-3 cells. In our study, we used a similar dose 200 $\mu \mathrm{M}$ for ALA, a slightly lower dose than the IC50. The mRNA expressions of SOD-1, SOD-2, catalase, and GSH-Px were also found to be decreased by ALA in PC-3 with 125, 50 and 500 $\mu \mathrm{M}$ treatment along with an increase of Ref-1 protein, which has multifunctional roles involved in oxidative DNA damage repair (65). In the current study, ALA were found to increase the cytotoxicity of the estrogen receptor agonist phthalates (51), BBP, DIBP and DBP significantly. According to current literature, information regarding ALA and estrogen receptor is missing. Therefore, current study might provide a preliminary information for the mechanism of action of ALA through estrogen receptor (especially Er $\alpha$ ).

\section{Conclusion}

Future directions on the development of effective therapeutic strategy for the prostate cancer would be linked to the effective control on the hormonal and neuroendocrine transdifferentiation pathways. Meanwhile, various molecular differences of the tumor type and epigenetic factors including endocrine disrupting compounds, like phthalates, makes the accurate treatment difficult and the progression more aggressive. Combination therapies to reduce the resistance of chemotherapeutics, such as antioxidants would be directed. In the current study, the responses of two different cell lines DU-145 and PC3 on exposure to phthalates were found to be different and the cytotoxic effects of estrogen receptor agonist phthalates (DIBP, DBP and BBP) were found to increase the cytotoxic effects in PC3 cells, which are known to be a more aggressive tumor type than DU145 cells. Even though the current study has the limitation of providing in vitro data that might not carry over to in vivo conditions, it could be suggested that the combination ALA upon exposure to estrogenic environmental contaminants might be beneficial for the progression of the prostatic tumor.

\section{References}

1. Mottet N, Bellmunt J, Briers E, Bolla M, Cornford P, De Santis M, Henry A, Joniau S, Lam T, Mason MD, Matveev V, van der Poel H, van der Kwast TH, Rouviére O, Wiegel RT, Guidelines Associates: van den Bergh RCN, van den Broeck T, van Casteren NJ, Everaerts W, Marconi L, Moldovan P. EAU (European Association of Urology)-ESTRO (European Society for Radiotherapy and Oncology)-SIOG (International Society of Geriatric Oncology) Guidelines on Prostate Cancer 2016. (cited 2016 Dec 18). Available from: http://uroweb.org/wp-content/uploads/ EAU-Guidelines-Prostate-Cancer-2016.pdf.

2. Packer L, Witt EH, Tritschler HJ. Alpha-lipoic acid as a biological antioxidant. Free Radic Biol Med 1995; 19: 227-250.

3. Novotny L, Rauko P, Cojocel C. Alpha-Lipoic acid: the potential for use in cancer therapy. Neoplasma 2008; 55: 81-86.
4. Moungjaroen J, Nimmannit U, Callery PS, Wang L, Azad N, Lipipun V, Chanvorachote P, Rojanasakul Y. Reactive oxygen species mediate caspase activation and apoptosis induced by lipoic acid in human lung epithelial cancer cells through Bcl-2 down-regulation. J Pharmacol Exp Ther 2006; 319: 1062-1069.

5. Puchsaka P, Chaotham C, Chanvorachote P. $\alpha$-Lipoic acid sensitizes lung cancer cells to chemotherapeutic agents and anoikis via integrin $\beta 1 /$ $\beta 3$ downregulation. Int J Oncol 2016; 49: 1445-1456.

6. Wenzel U, Nickel A, Daniel H. $\alpha$-lipoic acid induces apoptosis in human colon cancer cells by increasing mitochondrial respiration with a concomitant $\mathrm{O}^{2-}$.-generation. Apoptosis 2005; 10: 359-368.

7. Na MH, Seo EY, Kim WK. Effects of $\alpha$-lipoic acid on cell proliferation and apoptosis in MDA-MB-231 human breast cells. Nutr Res Pract 2009; 3: 265-271.

8. Dozio E, Ruscica M, Passafaro L, Dogliotti G, Steffani L, Marthyn P, Pagani A, Demartini G, Esposti D, Fraschini F, Magni P. The natural antioxidant alpha-lipoic acid induces p27(Kip1)-dependent cell cycle arrest and apoptosis in MCF-7 human breast cancer cells. Eur J Pharmacol 2010; 641: 29-34.

9. Selvakumar E, Hsieh TC. Regulation of cell cycle transition and induction of apoptosis in HL-60 leukemia cells by lipoic acid: role in cancer prevention and therapy. J Hematol Oncol 2008; 1: 4.

10. Alpay M, Yurdakok-Dikmen B, Kismali G, Sel T. Antileukemic effects of piperlongumine and alpha lipoic acid combination on Jurkat, MEC1 and NB4 cells in vitro. J Cancer Res Ther 2016; 12: 556-560.

11. Shi DY, Liu HL, Stern JS, Yu PZ, Liu SL. Alpha-lipoic acid induces apoptosis in hepatoma cells via the PTEN/Akt pathway. FEBS Lett 2008; 582: $1667-1671$.

12. Gorąca A, Huk-Kolega H, Piechota A, Kleniewska P, Ciejka E, Skibska B. Lipoic acid - biological activity and therapeutic potential. Pharmacol Rep 2011; 63: 849-858.

13. Suzuki YJ, Aggarwal BB, Packer L. Alpha-lipoic acid is a potent inhibitor of NF-kappa B activation in human T cells. Biochem Biophys Res Commun 1992; 189: 1709-1715.

14. Packer L. alpha-Lipoic acid: a metabolic antioxidant which regulates NF-kappa B signal transduction and protects against oxidative injury. Drug Metab Rev 1998; 30: 245-275.

15. Lee HA, Hughes DA. Alpha-lipoic acid modulates NF-kappaB activity in human monocytic cells by direct interaction with DNA. Exp Gerontol 2002; 37: 401-410.

16. van de Mark K, Chen JS, Steliou K, Perrine SP, Faller DV. Alpha-lipoic acid induces p27Kip-dependent cell cycle arrest in non-transformed cell lines and apoptosis in tumor cell lines. J Cell Physiol 2003; 194: 325-340.

17. Miadoková E, Vlcková V, Dúhová V. Antimutagenic effect of alphalipoic acid on three model test systems. Pharmazie 2000; 55: 862-863.

18. Unal F, Taner G, Yuzbasioglu D, Yilmaz S. Antigenotoxic effect of lipoic acid against mitomycin-C in human lymphocyte cultures. Cytotechnology 2013; 65: 553-565.

19. Gedlicka C, Scheithauer W, Schüll B, Kornek GV. Effective treatment of oxaliplatin-induced cumulative polyneuropathy with alpha-lipoic acid. J Clin Oncol 2002; 20: 3359-3361.

20. Melli G, Taiana M, Camozzi F, Triolo D, Podini P, Quattrini A, Taroni F, Lauria G. Alpha-lipoic acid prevents mitochondrial damage 
and neurotoxicity in experimental chemotherapy neuropathy. Exp Neurol 2008; 214: 276-284.

21. De-Stefani E, Deneo-Pellegrini H, Boffetta P, Ronco A, Mendilaharsu M. . Alpha-linolenic acid and risk of prostate cancer: a case-control study in Uruguay. Cancer Epidemiol Biomark Prev 2000; 9: 335-338.

22. Brouwer IA, Katan MB, Zock PL. Dietary alpha-linolenic acid isassociated with reduced fatal coronary heart disease, but increased prostatecancer risk: a meta-analysis. J Nutr 2014; 134: 919-922.

23. Azrad M, Zhang K, Vollmer RT, Madden J, Polascik TJ, Snyder DC, Ruffin MT, Moul JW, Brenner D, Hardy RW, Demark-Wahnefried W. Prostatic alpha-linolenic acid (ALA) is positively associated with aggressive prostate cancer: a relationship which may depend on genetic variation in ALA metabolism. PLoS One 2012; 7: e53104.

24. Simon JA, Chen YH, Bent S. The relation of alpha-linolenic acid to the risk of prostate cancer: a systematic review and meta-analysis. Am J Clin Nutr 2009; 89: 1558S-1564S.

25. Wittassek M, Koch HM, Angerer J, Bruning T. Assessing exposure to phthalates - the human biomonitoring approach. Mol Nutr Food Res 2011; 55: 7-31.

26. Latini G, Del Vecchio A, Massaro M, Verrotti A, De Felice C. Phthalate exposure and male infertility. Toxicology 2016; 226: 90-98.

27. Kay VR, Bloom MS, Foster WG. Reproductive and developmental effects of phthalate diesters in males. Crit Rev Toxicol 2014; 44: 467-498.

28. Nabae K, Doi Y, Takahashi S, Ichihara T, Toda C, Ueda K, Okamoto $Y$, Kojima $N$,

29. Tamano S, Shirai T. Toxicity of di(2-ethylhexyl)phthalate (DEHP) and di(2-ethylhexyl)adipate (DEHA) under conditions of renal dysfunction induced with folic acid in rats: enhancement of male reproductive toxicity of DEHP is associated with an increase of the mono-derivative. Reprod Toxicol 2006; 22: 411-417.

30. Saillenfait AM, Sabate JP, Gallissot F. Diisobutyl phthalate impairs the androgen-dependent reproductive development of the male rat. Reprod Toxicol 2008; 26: 107-115.

31. Lee HR, Hwang KA, Choi KC. The estrogen receptor signaling pathway activated by phthalates is linked with transforming growth factor- $\beta$ in the progression of $\mathrm{LNCaP}$ prostate cancer models. Int J Oncol 2014; 45: 595-602.

32. Hruba E, Pernicova Z, Palkova L, Soucek K, Vondracek J, Machala M. Phthalates deregulate Cell proliferation, but not neuroendocrine tansdifferentiation, in human LNCaP prostate cancer cell Model. Folia Biol (Praha) 2014; 60 (Suppl 1): 56-61.

33. Erkekoğlu P, Rachidi W, De Rosa V, Giray B, Favier A, Hincal, F. Protective effect of selenium supplementation on the genotoxicity of di(2-ethylhexyl)phthalate and mono(2-ethylhexyl)phthalate treatment in LNCaP cells. Free Radic Biol Med 2010; 49: 559-566.

34. El-Beshbishy HA, Mariah RA, Al-Azhary NM, Aly HA, Ozbak HA, Baghdadi HH. Influence of lipoic acid on testicular toxicity induced by bi-n-butyl phthalate in rats. Food Chem Toxicol 2014; 71: 26-32.

35. Dozmorov MG, Hurst RE, Culkin DJ, Kropp BP, Frank MB, Osban J, Penning TM, Lin HK. Unique patterns of molecular profiling between human prostate cancer LNCaP and PC-3 cells. Prostate 2009; 69: 1077-1090.

36. Tai S, Sun Y, Squires JM, Zhang H, Oh WK, Liang CZ, Huang J. $\mathrm{PC} 3$ is a cell line characteristic of prostatic small cell carcinoma. Prostate 2011; 71: 1668-1679.
37. Prins GS. Endocrine disruptors and prostate cancer risk. Endocr Relat Cancer 2008; 15: 649-656.

38. Hu WY, Shi GB, Hu DP, Nelles JL, Prins GS. Actions of estrogens and endocrine disrupting chemicals on human prostate stem/progenitor cells and prostate cancer risk. Mol Cell Endocrinol 2012; 354: 63-73.

39. Alavanja MC, Samanic C, Dosemeci M, Lubin J, Tarone R, Lynch CF, Knott C, Thomas K, Hoppin JA, Barker J, Coble J, Sandler DP, Blair A. Use of agricultural pesticides and prostate cancer risk in the Agricultural Health Study cohort. Am J Epidemiol 2003; 157: 800-814.

40. Meyer TE, Coker AL, Sanderson M, Symanski E. A case-control study of farming and prostate cancer in African-American and Caucasian men. Occup Environ Med 2007; 64: 155-160.

41. Mahajan R, Blair A, Lynch CF, Schroeder P, Hoppin JA, Sandler DP, Alavanja MC. Fonofos exposure and cancer incidence in the agricultural health study. Environ Health Perspect 2006; 114: 1838-1842.

42. Gao H, Yang BJ, Li N, Feng LM, Shi XY, Zhao WH, Liu SJ. Bisphenol A and hormone-associated cancers: current progress and perspectives. Medicine (Baltimore) 2015; 94: e211.

43. Ritchie JM, Vial SL, Fuortes LJ, Guo H, Reedy VE, Smith EM. Organochlorines and risk of prostate cancer. J Occup Environ Med 2003; 45: 692-702.

44. Leng L, Chen X, Li CP, Tang, NJ. 2,3,7,8-Tetrachlorodibezo-p-dioxin exposure and prostate cancer: a meta-analysis of cohort studies. Public Health 2014; 128: 207-213.

45. Waalkes MP, Rehm S. Cadmium and prostate cancer. J Toxicol Environ Health. 1994; 43: 251-269.

46. Benbrahim-Tallaa L, Waalkes MP. Inorganic arsenic and human prostate cancer. Environ Health Perspect 2008; 116: 158-164.

47. Nelles JL, Hu W-Y, Prins GS. Estrogen action and prostate cancer. Expert Rev Endocrinol Metab 2011: 6: 437-451.

48. Nelson AW, Tilley WD, Neal DE, Carroll JS. Estrogen receptor beta in prostate cancer: friend or foe? Endocr Relat Cancer 2014; 21: T219-T234.

49. Carruba G, Pfeffer U, Fecarotta E. Estradiol inhibits growth of hormone-nonresponsive PC3 human prostate cancer cells. Cancer Res. 1994; 54: 1190-1193.

50. Matsumura K, Tanaka T, Kawashima H, Nakatani T. Involvement of the estrogen receptor beta in genistein-induced expression of p21(waf1/ cip1) in PC-3 prostate cancer cells. Anticancer Res 2008; 28: 709-714.

51. Lau KM, LaSpina M, Long J, Ho SM. Expression of estrogen receptor (ER)-alpha and ER-beta in normal and malignant prostatic epithelial cells: regulation by methylation and involvement in growth regulation. Cancer Res 2000; 60: 3175-3182.

52. Takeuchi S, Iida M, Kobayashi S, Jin K, Matsuda T, Kojima H. Differantial effects of phthalate ester on transcriptional activities via human estrogen receptors alpha, and beta, and androgen receptors. Toxicology 2005; 210: 223-233.

53. van Bokhoven A, Varella-Garcia M, Korch C, Johannes WU, Smith EE, Miller HL, Nordeen SK, Miller GJ, Lucia MS. Molecular characterization of human prostate carcinoma cell lines. Prostate 2003; 57: 205-225.

54. Alimirah F, Chen J, Basrawala Z, Xin H, Choubey D. DU-145 and PC-3 human prostate cancer cell lines express androgen receptor: implications for the androgen receptor functions and regulation. FEBS Lett 2006; 580: 2294-2300. 
460-466

55. Yuan TC, Veeramani S, Lin FF, Kondrikou D, Zelivianski S, Igawa T, Karan D, Batra SK, Lin MF. Androgen deprivation induces human prostate epithelial neuroendocrine differentiation of androgen-sensitive LNCaP cells. Endocr Relat Cancer 2006; 13: 151-167.

56. Christoforou P, Christopoulos PF, Koutsilieris M. The role of estrogen receptor $\beta$ in prostate cancer. Mol Med 2014; 20 : 427-434.

57. Kowalska K, Piastowska-Ciesielska AW. Oestrogens and oestrogen receptors in prostate cancer. Springerplus 2016; 5: 522.

58. Grigore AD, Ben-Jacob E, Farach-Carson MC. Prostate cancer and neuroendocrine differentiation: more neuronal, less endocrine? Front Oncol 2015; 5: 37.

59. Marchiani S, Tamburrino L, Nesi G, Paglierani M, Gelmini S, Orlando C, Maggi M, Forti G, Baldi E. Androgen-responsive and -unresponsive prostate cancer cell lines respond differently to stimuli inducing neuroendocrine differentiation. Int J Androl 2010; 33: 784-793.

60. Erkekoğlu P, Rachidi W, Yüzügüllü OG, Giray B, Oztürk M, Favier A, Hincal F. Induction of ROS, p53, p21 in DEHP- and MEHP-exposed LNCaP cells-protection by selenium compounds. Food Chem Toxicol 2011; 49: 1565-1571.
61. Lagarde F, Beausoleil C, Belcher SM, Belzunces LP, Emond C, Guerbet M, Rousselle C. Non-monotonic dose-response relationships and endocrine disruptors: a qualitative method of assessment. Environ Health 2015; 14: 13.

62. Yurdakok Dikmen B, Alpay M, Kismali G, Filazi A, Kuzukiran O, Sireli UT. In vitro effects of phthalate mixtures on colorectal adenocarcinoma cell lines. J Environ Pathol Toxicol Oncol 2015; 34: 115-123.

63. Hsu PC, Kuo YT, Leon Guo Y, Chen JR, Tsai SS, Chao HR, Teng YN, Pan MH. The adverse effects of low-dose exposure to Di(2-ethylhexyl) phthalate during adolescence on sperm function in adult rats. Environ Toxicol 2016; 31: 706-712.

64. Hirai S, Naito M, Kuramasu M, Ogawa Y, Terayama H, Qu N, Hatayama N, Hayashi S, Itoh M. Low-dose exposure to di-(2-ethylhexyl) phthalate (DEHP) increases susceptibility to testicular autoimmunity in mice. Reprod Biol 2015; 15: 163-171.

65. Choi S, Min K, Choi I, Kang D. Effects of $\alpha$-lipoic acid on the antioxidant system in prostate cancer cells. Korean J Urol 2009; 50: 72-80.

Received March 13, 2017. Accepted April 19, 2017. 